\title{
ANO1 (TMEM16A) in pancreatic ductal adenocarcinoma (PDAC)
}

\author{
D. R. P. Sauter - I. Novak - S. F. Pedersen - E. H. Larsen • \\ E. K. Hoffmann
}

Received: 5 March 2014 /Revised: 22 July 2014 / Accepted: 11 August 2014 / Published online: 28 August 2014

(C) The Author(s) 2014. This article is published with open access at Springerlink.com

\begin{abstract}
Pancreatic ductal adenocarcinoma (PDAC) has one of the worst survival rates of all cancers. ANO1 (TMEM16A) is a recently identified $\mathrm{Ca}^{2+}$-activated $\mathrm{Cl}^{-}$channel $(\mathrm{CaCC})$ that is upregulated in several tumors. Although ANO1 was subject to extensive studies in the recent years, its pathophysiological function has only been poorly understood. The aim of the present study is to establish the significance of ANO1 in PDAC behavior and demarcate its roles in PDAC from those of the volume-regulated anion channel (VRAC). We performed qPCR and Western blot measurements on different PDAC cell lines (Panc-1, Mia PaCa 2, Capan-1, AsPC-1, BxPC-3) and compared the results to those obtained in a human pancreatic ductal epithelium (HPDE) cell line. All cancer cell lines showed an upregulation of ANO1 on mRNA and protein levels. Whole-cell patch-clamp recordings identified large $\mathrm{Ca}^{2+}$ and voltage-dependent $\mathrm{Cl}^{-}$currents in PDAC cells. Using siRNA knockdown of ANO1 and three

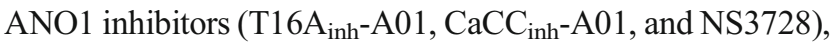
we found that $\mathrm{ANO} 1$ is the main constituent of $\mathrm{CaCC}$ current in PDAC cells. We further characterized these three inhibitors and found that they had unspecific effects on the free intracellular calcium concentration. Functional studies on PDAC behavior showed that surprisingly inhibition of ANO1 did not influence cellular proliferation. On the other hand, we
\end{abstract}

Electronic supplementary material The online version of this article (doi:10.1007/s00424-014-1598-8) contains supplementary material, which is available to authorized users.

D. R. P. Sauter $(\bowtie) \cdot$ S. F. Pedersen $•$ E. K. Hoffmann

Section for Cell and Developmental Biology, Department of Biology, University of Copenhagen, August Krogh Building,

Universitetsparken 13, 2100 Copenhagen Ø, Denmark

e-mail: Daniel.Sauter@bio.ku.dk

I. Novak • E. H. Larsen

Section for Molecular Integrative Physiology, Department of Biology, University of Copenhagen, August Krogh Building, Universitetsparken 13, 2100 Copenhagen Ø, Denmark found ANO1 channel to be pivotal in PDAC cell migration as assessed in wound healing experiments.

Keywords $\mathrm{Cl}^{-}$channel $\cdot$ TMEM16A $\cdot$ VRAC $\cdot$ LRRC8 $~$ Cancer $\cdot$ Proliferation $\cdot$ Migration $\cdot$ Pancreas

\section{Introduction}

Pancreatic ductal adenocarcinoma (PDAC) has one of the worst prognoses of all cancers, with a 5-year survival rate of less than $5 \%$. Incidence of PDAC correlates with increasing age and therefore is an increasing problem as world population is aging [16]. Dysfunction of ion channels is an emerging field in cancer research and differential expression of multiple classes of ion channels has been reported for different cancer tissues [20-22, 28, 29, 31, 35, 43]. Plasma membrane ion channels are involved in apoptosis [19], differentiation, and proliferation $[17,28]$, and are further associated with cell migration $[15,38]$ and cell volume regulation [14]. The latter is a crucial factor in regulation of cell proliferation (see [14]) and apoptosis [33], key processes that are usually deregulated in cancer [11].

In epithelia, including pancreatic ducts, $\mathrm{Ca}^{2+}$-activated $\mathrm{Cl}^{-}$ channel $(\mathrm{CaCC})$ is important for secretory processes [27]. One of the favored molecular candidates for $\mathrm{CaCC}$ is the recently identified ANO1 (also known as TMEM16A, TAOS2, ORAOV2, and DOG1) $[4,9,37,48]$. ANO1 is located on the amplicon 11q13 that is frequently amplified in human cancers with poor prognosis $[1,7,26,46]$. ANO1 was shown to be upregulated in several cancer tissues including head and neck squamous cell carcinoma (HNSCC) and prostate-, breast-, and pancreatic cancer [1, 2, 22, 23, 45]. However, the physiological function of ANO1 has been found to vary among different cancer tissues. A pro-proliferative role of ANO1 was reported for breast- and prostate cancer [3, 22, 
23], but this was not confirmed in HNSCC cells [1, 35]. Contradictory results are reported in the pancreatic cancer cell line CFPAC-1. Thus, Ruiz et al. [35] found a slight antiproliferative effect of ANO1 using a knockdown and an overexpression strategy, whereas Mazzone et al. [23] showed a decrease in proliferation after application of the recently developed ANO1-specific inhibitor T16 $\mathrm{A}_{\text {inh }}$-A01 $(10 \mu \mathrm{M})$ $[5,23,35]$. ANO1 was further associated with cellular attachment, spreading, detachment, and invasion $[1,15]$. All these studies used cell lines highly overexpressing ANO1 or with knockdown of ANO1 to assess its pathophysiological function, but suffered from the lack of a normal pancreatic epithelial cell control system for comparison.

A volume-regulated anion channel (VRAC), which is involved in restoring cell volume upon external osmotic perturbation, has been studied in several types of mammalian cells [14]. Synthesis of high-affinity $\mathrm{Cl}^{-}$channel inhibitors, such as NS3728 [12], has facilitated insight in VRAC's physiological role in cell cycle progression. A four-transmembrane protein, the Leucinerich repeat-containing protein 8 (LRRC8), was recently identified as a main constituent of the VRAC current $[32,44]$.

The aim of the present study was to elucidate the role of ANO1 in PDAC behavior, compare it to a normal model cell line, and demarcate the roles of ANO1 from those of VRAC.

\section{Materials and methods}

\section{Cell culture and transfection}

All cell lines were grown at $37{ }^{\circ} \mathrm{C}$ and $5 \% \mathrm{CO}_{2}$. Immortalized human pancreatic ductal epithelium (HPDE) (H6c7 cell line, kind gift of Dr. M-S. Tsao from University Health Network in Toronto $[8,27])$ cells were grown in keratinocyte serum-free medium supplemented by epidermal growth factor and bovine pituitary extract (Life Technologies, Inc., USA). Cells were passaged by gently trypsinization, subsequent neutralization with trypsin inhibitor (soybean, Life Technologies, Inc., USA), centrifugation (700 $\mathrm{rpm} / 3 \mathrm{~min})$, and resuspension. All cancer cells (obtained from ATCC, Germany) were passaged every 4-6 days by gently trypsinization. Panc- 1 and Mia PaCa-2 were grown in Dulbecco's Modified Eagle Medium with stable glutamine (DMEM/Biochrom, Germany), BxPC-3 and AsPC-1 in Roswell Park Memorial Institute medium with stable glutamine (RPMI 1640/Biochrom, Germany), and Capan-1 in Iscove's Modified Dulbecco's Medium (IMDM-1640/Biochrom, Germany), all were supplemented with $10 \% v / v$ (20\% for Capan-1) Fetal Bovine Serum "Gold" (PAA Laboratories $\mathrm{GmbH}$, Germany). Mia PaCa-2 growth medium was further supplemented with $2.5 \% \mathrm{v} / \mathrm{v}$ horse serum (Biochrom, Germany). All cultures were further supplemented with $1 \%$ $v / v$ penicillin and streptomycin.
DharmaFECT 1 Transfection Reagent (Thermo Scientific, Germany) was used for transfection of siRNA targeting ANO1 (50 nM final concentration) or scrambled ( $5 \mathrm{nM}$ final concentration). Cells were transfected according to the manufacturer's protocol. Predesigned siRNA oligo was obtained from Sigma-Aldrich (5'-CCUUCAACGUCAGUGA CUU[dT][dT]-3', 5'-AAGUCACUGACGUUGA AGG[dT][dT]-3') or negative control (Silencer ${ }^{\circledR}$ Negative Control No. 1 siRNA; Ambion, Denmark). ANO1 overexpressing HEK293 cells were generated by adding $0.5 \mu \mathrm{g} / \mathrm{ml}$ mANO1-GFP vector to DMEM containing $1 \% v / v$ penicillin and streptomycin. The mixture was vortexed and incubated for $5 \mathrm{~min}$, and $20 \mu \mathrm{g} / \mathrm{ml}$ polyethylenimine (PEI) was added. The mixture was vortexed again and added drop-wise to $60 \%$ confluent HEK293 cells in DMEM medium containing $5 \%$ $v / v$ FBS and $1 \% v / v$ penicillin and streptomycin after $10 \mathrm{~min}$ incubation at room temperature. Media was changed after $4 \mathrm{~h}$ incubation at $37{ }^{\circ} \mathrm{C}$ and $5 \% \mathrm{CO}_{2}$.

Isolation of RNA, cDNA, and qPCR

Total RNA was extracted from cell cultures using Nucleo Spin II (MACHEREY-NAGEL, Germany). First strand complementary DNAs were synthesized using Superscript II (Invitrogen, Denmark) and Oligo-dTs following the manufacturer's guidelines. PCR reaction mixtures were prepared using the FastStart Universal SYBR Green Master (Rox) mix (Roche, Denmark). Quantitative PCR experiments were carried out in triplicates. Primers used were as follows: ANO1sense 5'-GCGTCCACATCATCAACATC-3' and ANO1antisense $5^{\prime}$-ATCCTCGTGGTAGTCCATCG-3' [41]. ANO1 expression levels were normalized to the reference gene $\beta$ actin. The fold-change in gene expression was determined by the $\Delta \Delta C(t)$ method [36]. Data were expressed as expression relative to that in the control cell line HPDE.

\section{Electrophysiology}

Cells were grown on poly-L-lysine coated coverslips. For knockdown experiments, cells were transfected with siRNA targeting ANO1 or scrambled siRNA shortly after complete attachment of the cells (approx. $3 \mathrm{~h}$ after plating). Currents were measured 36-48 $\mathrm{h}$ after transfection. Whole-cell patchclamp recordings were performed using the Axopatch 200B amplifier interfaced to a Digidata 1440 A controlled by pClamp10 software (Molecular Devices, USA). Analogue signals were acquired at $2.5 \mathrm{kHz}$ and filtered at $1 \mathrm{kHz}$. Patch electrodes were pulled from borosilicate glass and had an input resistance of 2-6 $\mathrm{M} \Omega$, when filled with pipette solution (below). An agar bridge made of $3 \%$ agar and $97 \%$ of the bath solution containing NMDG-Cl (below) was used as reference electrode. Current activations were recorded from an output holding potential, $V_{\text {out }}=0 \mathrm{mV}$ with ramp protocols 
spanning from -100 to $100 \mathrm{mV}$ over $1 \mathrm{~s}$ and run continuously with 15 -s intervals. Step protocols between -100 to $120 \mathrm{mV}$ were generated from $V_{\text {out }}=0 \mathrm{mV}$ with step increments of $20 \mathrm{mV}$ and lengths of $2 \mathrm{~s}$. Liquid junction potentials $\left(V_{\mathrm{lj}}\right)$ were estimated as described in [10] with membrane potentials calculated as, $V_{\mathrm{m}}=V_{\text {out }}-V_{\mathrm{lj}}$. Series resistance was compensated by $60-70 \%$. All recordings were performed at room temperature $\left(18-23{ }^{\circ} \mathrm{C}\right)$. Instantaneous currents were measured $1 \mathrm{~ms}$ after each voltage step. The data was fitted using the Goldman-Hodgkin-Katz (GHK) current equation.

$I_{\mathrm{Cl}^{-}}=P \frac{z^{2} F^{2} V C_{o}-C_{i} e^{\frac{z F V}{R T}}}{R T \quad 1-e^{\frac{z F V}{R T}}}$

Here, $I_{\mathrm{Cl}^{-}}$is the current carried across the membrane by $\mathrm{Cl}^{-}$ions, $P$ is the permeability of the membrane for $\mathrm{Cl}^{-}, z$ is the valence $(-1), F$ is the Faraday constant, $V$ is the membrane voltage, $R$ is the universal gas constant, $T$ is the absolute temperature, $C_{o}$ and $C_{i}$ are the extra- and intracellular concentration of $\mathrm{Cl}^{-}$, respectively. Steady-state permeability was calculated by solving Eq. 1 for $P$. The Boltzmann distribution (Eq. 2) was fitted to the permeabilities obtained above.

$P_{\mathrm{Cl}}=P_{\max }+\frac{\left(P_{\min }-P_{\max }\right)}{1+e^{\frac{V-V_{1 / 2}}{d V}}}$

$V_{1 / 2}$ is the voltage for half-maximal activation of the channels. The curves were normalized to $P_{\min }=0$ and $P_{\max }=1$.

\section{Solutions}

One micromolar free $\mathrm{Ca}^{2+}$ pipette solution include the following (in mM): $100 \mathrm{CsAsp}, 40 \mathrm{CsCl}, 4.34 \mathrm{CaCl}_{2}, 4 \mathrm{Na}_{2} \mathrm{ATP}, 1$ $\mathrm{MgCl}_{2}, 5$ EGTA, 10 HEPES, pH 7.2, osmolality 295 mosmol/ $\mathrm{kg}$ or $0 \mu \mathrm{M}$ free $\mathrm{Ca}^{2+}$ solution containing no $\mathrm{CaCl}_{2}$ and $10 \mathrm{mM}$ EGTA. Standard bath solution include the following (in $\mathrm{mM}$ ): $150 \mathrm{NaCl}, 1.5 \mathrm{CaCl}_{2}, 1 \mathrm{MgCl}_{2}, 10$ glucose, 10 HEPES, pH 7.4, osmolality $315 \mathrm{mosmol} / \mathrm{kg}$ (adjusted with D-mannitol). Isotonic solution include the following (in $\mathrm{mM}$ ): $85 \mathrm{NaCl}, 2 \mathrm{MgCl}_{2}, 1.5$ $\mathrm{CaCl}_{2}, 10$ glucose, 10 HEPES, pH 7.4, of osmolality $315 \mathrm{mosmol} / \mathrm{kg}$ (adjusted with D-mannitol). The hypotonic solution with osmolality of $210 \mathrm{mosmol} / \mathrm{kg}$ was obtained by omitting D-mannitol from the isotonic solution. For experiments testing efficiency of an inhibitor, $\mathrm{NaCl}$ was replaced by $N$-methyl-D-glucamine chloride (NMDG-Cl) after seal formation. All osmolalities were measured in a Wescor Vapro model 5520 osmometer (Wescor Inc., USA) calibrated by the manufacturer's Optimol standard solutions.

\section{SDS-PAGE and Western blotting}

Protein was isolated from cells $36 \mathrm{~h}$ after transfection with siRNA targeting ANO1, in a lysis buffer containing (in $\mathrm{mM}$ ):
10 Tris- $\mathrm{HCl}, 10$ EDTA, $1 \%$ sodium dodecyl sulfate (SDS), $0.5 \%$ sodium deoxycholate, and $1 \%$ complete protease inhibitor mixture (Roche, Denmark), $\mathrm{pH} 7.4$, and was separated by $7 \%$ SDS-PAGE. Protein was subsequently transferred to nitrocellulose membrane (Novex, Denmark). Membranes were immunoblotted with monoclonal antibodies against ANO1 (SP31, ab64085) (Abcam, UK) or $\beta$-actin (Sigma-Aldrich, Denmark), at 1:100 and 1:3,000 dilutions, respectively, overnight at $4{ }^{\circ} \mathrm{C}$ in blocking buffer. Alkaline phosphatase-conjugated goat anti-rabbit (ANO1) or goat anti-mouse ( $\beta$-actin) secondary antibodies (both Sigma-Aldrich, Denmark) were used at a 1:500 dilution in blocking buffer for $1 \mathrm{~h}$ at room temperature. Membranes were washed extensively in Tris-buffered saline with Tween® 20 (TBST) and developed using BCIP/NBT solution (Kirkegaard and Perry Laboratories, USA).

\section{Cell proliferation and apoptosis assay}

To assess cell proliferation and apoptosis, cells were plated in duplicates on a 96-well plate and incubated in $100 \mu \mathrm{l}$ of the cell line appropriate media described above. Cells were transfected with siRNA soon after complete attachment (approx. $3 \mathrm{~h}$ after seeding). Cells were treated with vehicle, $20 \mu \mathrm{M}$ gemcitabine, $20 \mu \mathrm{M}$ T16 $\mathrm{A}_{\text {inh }}-\mathrm{A} 01$, or $10 \mu \mathrm{M}$ free NS3728 (see below) after culture in a humidified $37{ }^{\circ} \mathrm{C}$ and $5 \% \mathrm{CO}_{2}$ incubator overnight. BrdU incorporation was measured using Cell Proliferation ELISA, BrdU (chemiluminescent) (Roche Diagnostics A/S, Denmark) following the manufacturer's instructions. Caspases 3, 6, and 7 activation was evaluated using Homogeneous Caspases Assay (fluorimetric) (Roche Diagnostics A/S, Denmark).

\section{Scratch wound healing assay}

Cells were seeded into Essen ImageLock 96-well plates. Cells were transfected with siRNA shortly after cells completely attached at $80 \%$ confluency. After $24 \mathrm{~h}$ of incubation, confluent monolayers were scratched using the Essen 96-well WoundMaker (Essen Bioscience, USA), washed two times with the respective medium, and then incubated in medium containing $5 \mu \mathrm{M}$ aphidicolin (Sigma-Aldrich, Denmark) and either $\mathrm{T}_{16 \mathrm{~A}_{\mathrm{inh}}} \mathrm{A} 01, \mathrm{CaCC}_{\mathrm{inh}}-\mathrm{A} 01$, or NS3728 or the appropriate control. The wound confluence was obtained and analyzed by using the IncuCyte phase-contrast imaging and scratch wound assay system and software (Essen Bioscience, USA). Wound closure was assessed by comparing the mean relative wound density (\%RWD) according to the following formula: $\%$ RWD $=100 \times w(t)-w(0) / c(t)-w(t)$. Here, $w(t)$ is the density of wounded area at time $t$ and $c(t)$ is the density of cell region at time $t$. Each experiment was conducted in triplicates. 
Measurements of the free, intracellular calcium concentration, $\left[\mathrm{Ca}^{2+}\right]_{\mathrm{i}}$

HPDE and BxPC-3 cells were incubated with $2 \mu \mathrm{M}$ Fura-2 AM (Sigma-Aldrich, Denmark) for $30 \mathrm{~min}$ at $37{ }^{\circ} \mathrm{C}$. Cells were subsequently washed with Krebs solution containing (in $\mathrm{mM}$ ) $150 \mathrm{NaCl}, 6 \mathrm{KCl}, 1.5$ $\mathrm{CaCl}_{2}, 1 \mathrm{MgCl}_{2}, 10$ glucose, and 10 HEPES; $\mathrm{pH}$ was adjusted to 7.4 using $\mathrm{NaOH}$. Coverslips were mounted on a recording chamber. In the beginning of the experiment, cells were perfused with Krebs solution at $4 \mathrm{ml} /$ min until baseline was stable. Thereafter, the inhibitors

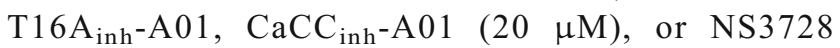
$(10 \mu \mathrm{M})$ were infused and cells were stimulated with general P2 receptor agonist ATP $(10 \mu \mathrm{M})$. Changes in $\left[\mathrm{Ca}^{2+}\right]_{\mathrm{i}}$ were measured by a TIRF iMIC microscope (TILL Photonics, Germany). Fura-2 AM loaded cells were illuminated at $340 \mathrm{~nm}$ for $80 \mathrm{~ms}$ and $380 \mathrm{~nm}$ for $80 \mathrm{~ms}$ at $1 \mathrm{~s}$ intervals using a TILL Polychrome monochromator. Five hundred-nanometer emission images were captured by an image-intensifying, chargecoupled device (CCD) camera (TILL Photonics, Germany) and digitized by an image processing system (TILL Photonics, Germany). The monochromator and CCD camera were controlled by LA Live Acquisition software, which was also used for image analysis. The $\left[\mathrm{Ca}^{2+}\right]_{\mathrm{i}}$ was presented as the Fura-2 ratio of the fluorescence signals obtained at $340 / 380 \mathrm{~nm}$.

Materials and statistical analysis

2 - [( 5 - Ethyl-1,6-dihydro-4-methy $1-6$ - oxo-2pyrimidinyl)thio]-N-[4-(4-methoxyphenyl)-2thiazolyl] acetamide (T16 $\left.\mathrm{A}_{\mathrm{inh}}-\mathrm{A} 01\right), 6-(1,1-$ dimethylethyl)-2-[(2-furanylcarbonyl)amino]-4,5,6,7tetrahydrobenzo[b]thiophene-3-carboxylic acid $\left(\mathrm{CaCC}_{\mathrm{inh}^{-}}\right.$ A01), and aphidicolin were obtained from SigmaAldrich at highest available purity. Stock solutions of $10 \mathrm{mM}$ were prepared using dimethyl sulfoxide (DMSO). The VRAC and CaCC inhibitor $\mathrm{N}-[3,5-$ bis(trifluoromethyl)-phenyl]-N-[4-bromo-2-(1H-tetrazol5-yl)-phenyl] urea (NS3728) was a generous gift from Palle Christophersen (NeuroSearch A/S, Denmark) (stock solution $100 \mathrm{mM}$ in DMSO). Earlier reports found NS3728 to strongly bind to serum [17, 33]. We therefore used NS3728 at $50 \mu \mathrm{M}$ for physiological assays such as proliferation, migration, and apoptosis assays, all performed in media containing serum. It is estimated that in these conditions the free inhibitor concentration amounted to $10 \mu \mathrm{M}$.

The results of multiple experiments are presented as means \pm s.e.m., and statistical analysis was carried out by using one-way analysis of variance with
Tukey's post test or Student's $t$ test, as appropriate. $P \leq 0.05$ was considered statistically significant.

\section{Results}

ANO1 is functionally overexpressed in PDAC cells and is the major mediator of $\mathrm{CaCC}$ current in these cells

To study the presence of ANO1 in PDAC cells, we evaluated the expression of ANO1 RNA by RT-qPCR in several commercially available cell lines (Mia PaCa-2, Panc-1, BxPC-3, and AsPC-1). Mia PaCa-2, Panc-1, and BxPC-3 were derived from the primary tumor of an exocrine pancreatic cancer. AsPC-1 was established from a local metastatic site in the ascites of a patient with PDAC [42]. We used a normal pancreatic ductal epithelium derived cell line (HPDE) as a control (Fig. 1). All cell lines showed an increased mRNA level, ranging from $2.3 \pm 0.5$ - to $320 \pm 60$-fold over that in HPDE cells, in the Panc-1 and BxPC-3 cell lines, respectively. Our earlier study compared ANO1 mRNA levels in Capan-1 PDAC cell line to Panc-1 and CFPAC-1 [45]; using those data together with the values for HPDE and Panc- 1 of the present investigation, we calculated an $\sim 1,450$-fold upregulation of ANO1 in Capan-1 with respect to HPDE cells. Capan-1 is a liver metastasis-derived cell line [42]. We selected the aggressive pancreatic cancer cell lines AsPC-1 and BxPC-3 [6], as well as Capan-1 and HPDE cells for further experiments. To validate ANO1 expression also at the protein level in PDAC cells, we used Western blot analysis (Fig. 1b). The results showed a similar trend as observed for mRNA levels, with almost undetectable ANO1 protein expression in HPDE cells and much higher levels in the PDAC cell lines.

The functional expression of the protein in the plasma membrane was assessed using the whole-cell patch-clamp technique (Fig. 2). The time-dependent current activation was recorded as described in "Materials and methods". Mean traces at $V_{\mathrm{m}}=+67 \mathrm{mV}$ with $1 \mu \mathrm{M}$ intracellular $\mathrm{Ca}^{2+}$ revealed a large voltage-dependent current with activation at positive membrane potentials in all cancer cell lines. This was most pronounced in Capan-1 cells and barely detectable in HPDE control cells (Fig. 2a). The instantaneous currents of the three cancer cell lines followed GHK rectification (Fig. 2b). It was thus possible to analyze steady-state permeability's using the GHK current equation (Fig. 2c). The instantaneous current-voltage curve of a few cells reversed at far more positive potentials as the calculated equilibrium potential for $\mathrm{Cl}^{-}$, those cells were omitted from the calculation of permeability. Capan-1 and AsPC-1 cells showed similar activation curves with half-maximal activation of the channels $\left(V_{1 / 2}\right)$ at $61 \pm 8$ and $58 \pm 8 \mathrm{mV}$, respectively. This is in good agreement with earlier studies in ANO1transfected HEK293 cells [47]. BxPC-3 cells exhibited a 
A

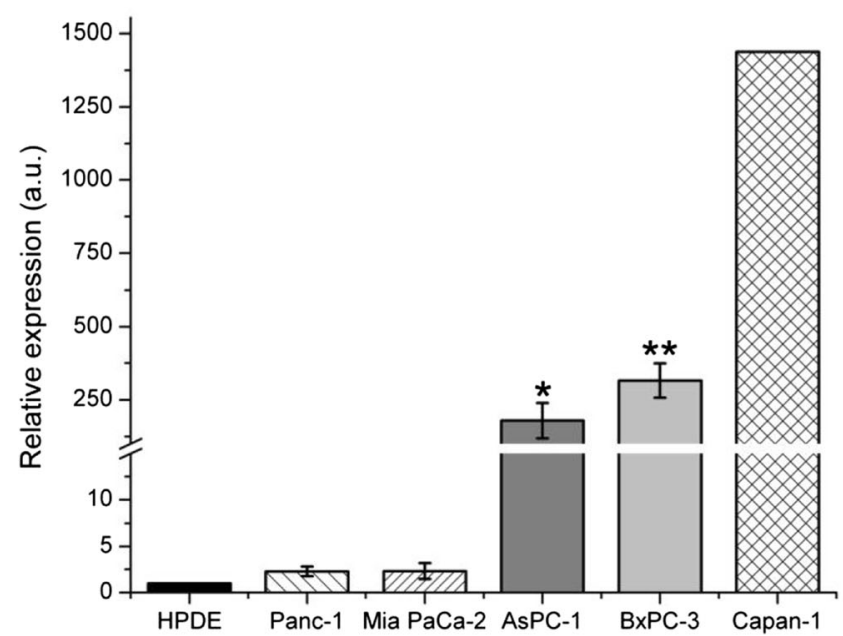

B
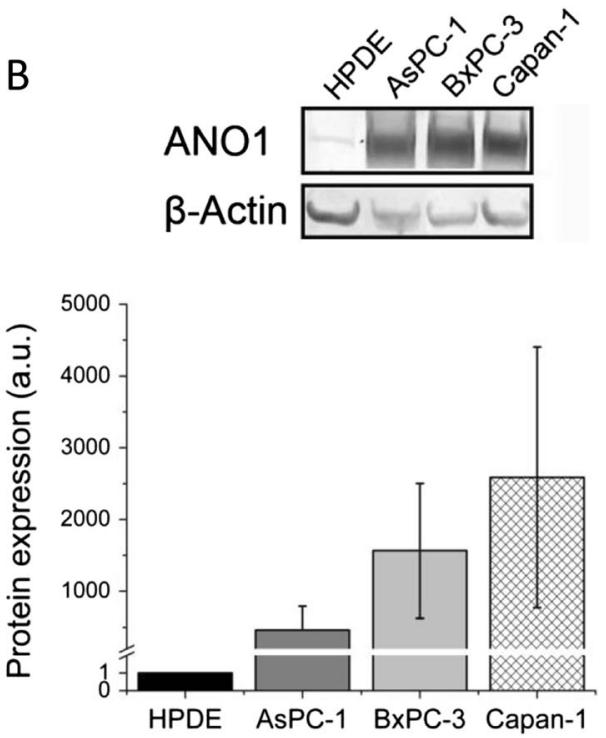

Fig. 1 ANO1 is upregulated at the mRNA and protein levels in all PDAC cell lines tested. a Mean ANO1 expressions measured by RT-qPCR in five PDAC cell lines (Panc-1, Mia PaCa-2, BxPC-3, AsPC-1, and Capan1) compared to the immortalized human pancreatic ductal cell line
(HPDE). Data for Capan-1 was taken from [45] and recalculated relative to the value in the HPDE cell line. b Western blot analysis in three pancreatic cancer cell lines and HPDE with $\beta$-actin as a loading control. Mean \pm s.e.m. of $n=4-5$ individual experiments significantly shifted permeability—voltage curve with $V_{1 / 2}=$ $30 \pm 8 \mathrm{mV}$. This altered gating in BxPC-3 cells may be due to differential expression of other possible modulators (e.g., calmodulin) or mutations in the voltage- or $\mathrm{Ca}^{2+}$-sensing first intracellular loop [47]. Further studies are needed to investigate this phenomenon. Steady-state current-voltage curves showed an outward-rectifying current with a reversal potential $\left(V_{\mathrm{Rev}}\right)$ close to the $\mathrm{Cl}^{-}$equilibrium potential $\left(\mathrm{E}_{\mathrm{Cl}}\right.$, Fig. $\left.2 \mathrm{~d}\right)$. Removal of $\mathrm{Ca}^{2+}$ from the pipette solution almost completely eliminated this current in the cancer cell lines (Fig. 2d). These biophysical properties match the characteristics described for ANO1 [48].

To quantify the ANO1-mediated part of the total $\mathrm{CaCC}$ current, we used siRNA knockdown, as well as the three $\mathrm{Cl}^{-}$ channel inhibitors NS3728 $(10 \mu \mathrm{M}), \mathrm{CaCC}_{\text {inh }}$-A01 $(20 \mu \mathrm{M})$,

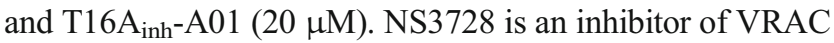
but was also found to inhibit $\mathrm{CaCC}$ [17]. $\mathrm{CaCC}_{\text {inh }}-\mathrm{A} 01$ is known to potently inhibit $\mathrm{CaCC}$ current but was further shown to alter $\left[\mathrm{Ca}^{2+}\right]_{\mathrm{i}}$ signals $[18]$. $\mathrm{T} 16 \mathrm{~A}_{\mathrm{inh}}-\mathrm{A} 01$ is the latest developed inhibitor of ANO1; no unspecific effects have been identified so far. Results are shown in Fig. 3. Application of $\mathrm{T} 16 \mathrm{~A}_{\text {inh }}$-A01 attenuated the $\mathrm{CaCC}$ current significantly in both Capan-1 (43 $\pm 8 \%$ inhibition at $+67 \mathrm{mV})$ and AsPC-1 $(29 \pm 2 \%)$ cells, but was ineffective on BxPC-3 cells (Fig. 3b). $\mathrm{CaCC}_{\text {inh }}-\mathrm{A} 01$ inhibited the current more effectively in all tested cell lines with $56 \pm 6 \%$ inhibition in Capan-1, 46 \pm $6 \%$ in AsPC-1, and $29 \pm 3 \%$ in BxPC-3 cells, respectively (all calculated at $+67 \mathrm{mV}$ ). Application of NS3728 resulted in the most pronounced inhibition in all cell lines with $77 \pm 26 \%$ in Capan- $1,67 \pm 9 \%$ in AsPC- 1 , and $54 \pm 8 \%$ in BxPC- 3 cells at $+67 \mathrm{mV}$. Using siRNA targeting $\mathrm{ANO} 1$, the $\mathrm{CaCC}$ currents decreased by $88 \pm 42 \%$ in Capan- $1,89 \pm 51 \%$ in AsPC- 1 , and $84 \pm 23 \%$ in BxPC-3 cells when compared to currents measured in cells transfected with scrambled siRNA (MOCK) (Fig. 3c). Successful knockdown of ANO1 protein expression was confirmed using Western blot (Fig. 3d). Protein expression was decreased to $37 \pm 8 \%$ in Capan- $1,54 \pm 14 \%$ in AsPC- 1 , and $20 \pm 7 \%$ in BxPC- 3 cells.

All tested cells exhibit a large volume-regulated anion current

The above results provide compelling evidence that ANO1 carries the major fraction of $\mathrm{CaCC}$ in PDAC cells. In order to further characterize the role of $\mathrm{Cl}^{-}$channels in PDAC cells, we next evaluated the role of the volume-regulated anion channel (VRAC or LRRC8), the genetic identity of which was recently identified $[34,44]$. We studied VRAC phenotype by whole-cell voltage-clamp recordings of cells exposed to a hypotonic bath solution and results are shown in Fig. 4. To rule out contributions from $\mathrm{CaCC}, \mathrm{Ca}^{2+}$ was omitted from the pipette solution and $10 \mathrm{mM}$ EGTA was included. A bath solution change from 315 to $210 \mathrm{mosmol} / \mathrm{kg}$ (removal of D-mannitol) caused the cells to swell and evoked a large current that was completely inhibited upon application of $10 \mu \mathrm{M}$ of NS3728 (Fig. 4a). Both the activation by volume expansion and the NS3728-mediated inhibition were reversible. The time course of swelling activation varied significantly among individual cells. However, large VRAC currents were detected in all tested cell lines with most prominent currents seen in Capan-1 and BxPC-3 cells (Fig. 4b). We also observed VRAC current inactivation at $V_{\mathrm{m}}>0 \mathrm{mV}$ with flat tail currents at depolarized membrane potentials, as also reported previously [30]. This voltage dependency of $I_{\mathrm{VRAC}}$ was pronounced in 


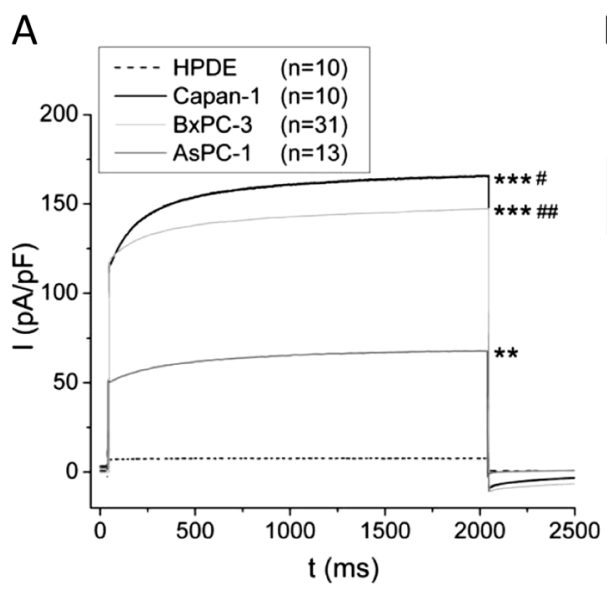

D
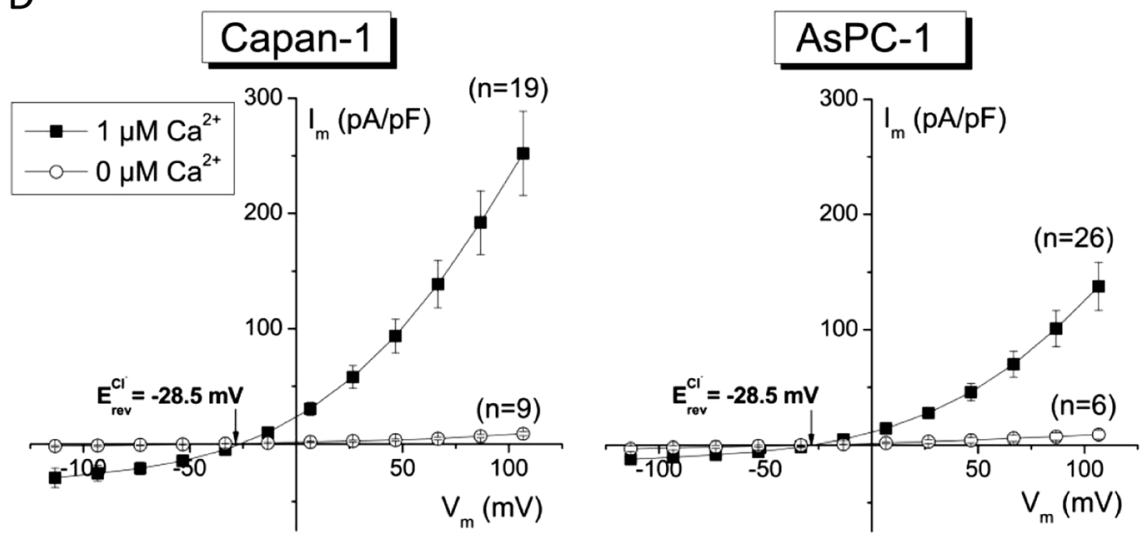

B

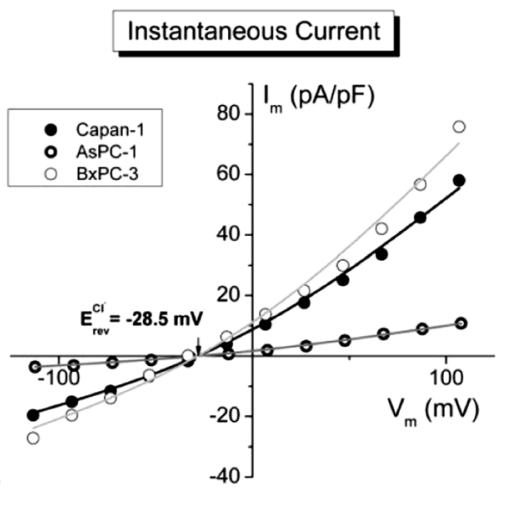

C

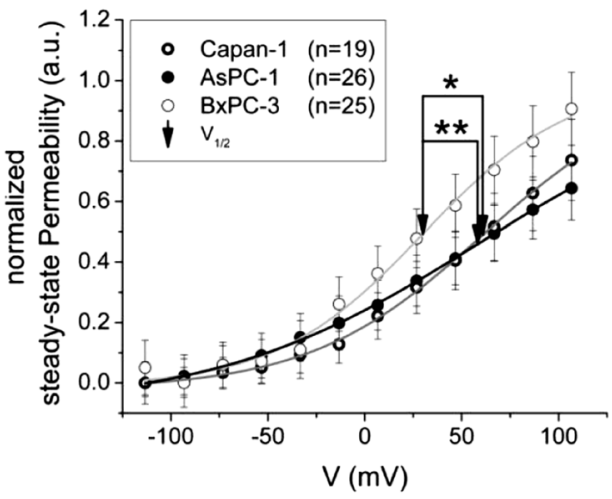

Fig. 2 PDAC cells exhibit large $\mathrm{Ca}^{2+}$ - and voltage-activated $\mathrm{Cl}^{-}$currents that were not detected in HPDE control cells. Whole-cell patch-clamp recordings in HPDE, Capan- 1 , AsPC- 1 , and BxPC-3 cells. $V_{\text {out }}=0 \mathrm{mV}$ and a pulse sequence from -100 to $+100 \mathrm{mV}$ of $20 \mathrm{mV}$ increments was applied as described in "Materials and methods." a Mean currents at + $67 \mathrm{mV}$. Statistical analysis was made at the end of the voltage step. b Representative instantaneous current-voltage relationships of the different cancer cell lines fitted to the GHK current equation. c Normalized steady-state permeability calculated using the GHK current equation and

HPDE and Capan-1 cells; BxPC-3 and AsPC-1 cells showed weaker inactivation at positive voltages (Fig. $4 \mathrm{~b}, \mathrm{c}$ ). It was recently suggested that VRAC is a heteromer formed by different subtypes of the LRRC8 protein family, which exhibit different gating at positive potential [44]. The apparent difference in gating between the cell lines might be due to differential expression of the different LRRC8 subtypes. However, further studies are required to confirm this. The $V_{\operatorname{Rev}}$ of the activated current was $-25.7 \pm 0.7 \mathrm{mV}$ (HPDE), $-24 \pm 2 \mathrm{mV}$ (Capan-1), $-24 \pm 2 \mathrm{mV}$ (AsPC-1), and $28 \pm 3 \mathrm{mV}$ (BxPC-3), as compared to the calculated $\mathrm{Cl}^{-}$equilibrium potential of $-20 \mathrm{mV}$ (Fig. $4 \mathrm{c}$ ).

$\mathrm{T}_{16 \mathrm{~A}_{\text {inh }}}-\mathrm{A} 01$ and $\mathrm{CaCC}_{\text {inh }}-\mathrm{A} 01$ do not inhibit VRAC; NS3728 is a potent inhibitor of both VRAC and ANO1

In order to evaluate the inhibitors of the two $\mathrm{Cl}^{-}$channels, we studied effects of the ANO1 inhibitors, $\mathrm{T}_{16 \mathrm{~A}_{\text {inh }}-\mathrm{A} 01 \text { and }}$ $\mathrm{CaCC}_{\text {inh }}-\mathrm{A} 01$, and of the VRAC inhibitor, NS3728, on fitted to the Boltzmann distribution. $V_{1 / 2}$ is the voltage for half-maximal activation of the channels. d Steady-state $I-V$ relationships of Capan-1, AsPC-1, and BxPC-3 cells in the presence and absence of intracellular $\mathrm{Ca}^{2+} .(n)=$ number of cells measured; asterisk, significant when compared to HPDE (ANOVA); number sign, significantly different from AsPC-1 cells; single asterisk and single number sign $=p \leq 0.05$; double asterisk and double number sign $=p \leq 0.01$; triple asterisk and triple number sign $=$ $p \leq 0.001$

volume-induced currents. Cells were exposed to hypotonic solution in the absence of intracellular $\mathrm{Ca}^{2+}$, and after full activation of the membrane current, the HPDE and BxPC-3 cells were

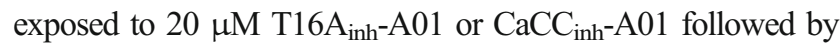
NS3728 (Fig. 5a, b). Statistical analyses of currents were performed at $V_{\mathrm{m}}=+65 \mathrm{mV}$ before and after application of the respective inhibitor (Fig. 5c). Neither $\mathrm{T}_{16 \mathrm{~A}_{\text {inh }}} \mathrm{A} 01$ nor $\mathrm{CaCC}_{\text {inh }}$-A01 inhibited the VRAC currents significantly. In

Fig. 3 ANO1 is the major contributor of $\mathrm{CaCC}$ currents in PDAC cells and is sensitive to $\mathrm{Cl}^{-}$channel inhibitors and siRNA. Whole-cell patchclamp recordings with $1 \mu \mathrm{M} \mathrm{Ca}^{2+}$ in pipette solution. a Representative current traces measured in Capan-1 cells upon exposure to different inhibitors. b Quantification of $\mathrm{CaCC}$ currents at $+67 \mathrm{mV}$ recorded with inhibitors compared to currents in presence of DMSO; currents of siANO1 cells were compared to those of MOCK transfected cells. c Steady-state $I-V$ relationships of cells transfected with either scrambled siRNA (MOCK) or siRNA targeting ANO1. d Densitometric quantification of Western blot analysis of siRNA knockdown. $\beta$-Actin was used as a loading control. $(n)=$ number of individual experiments 
A

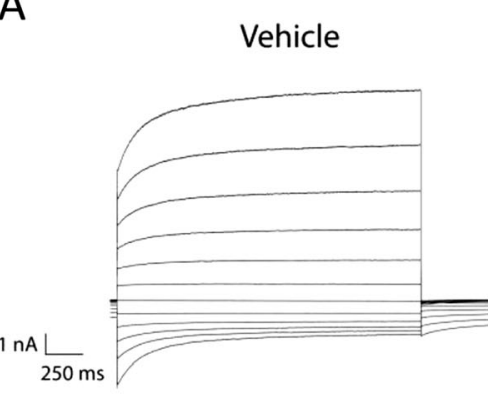

$\mathrm{T}_{16 \mathrm{~A}_{\text {inh }}}-\mathrm{A} 01$

$\mathrm{CaCC}_{\text {inh }}-\mathrm{A} 01$

NS3728

B

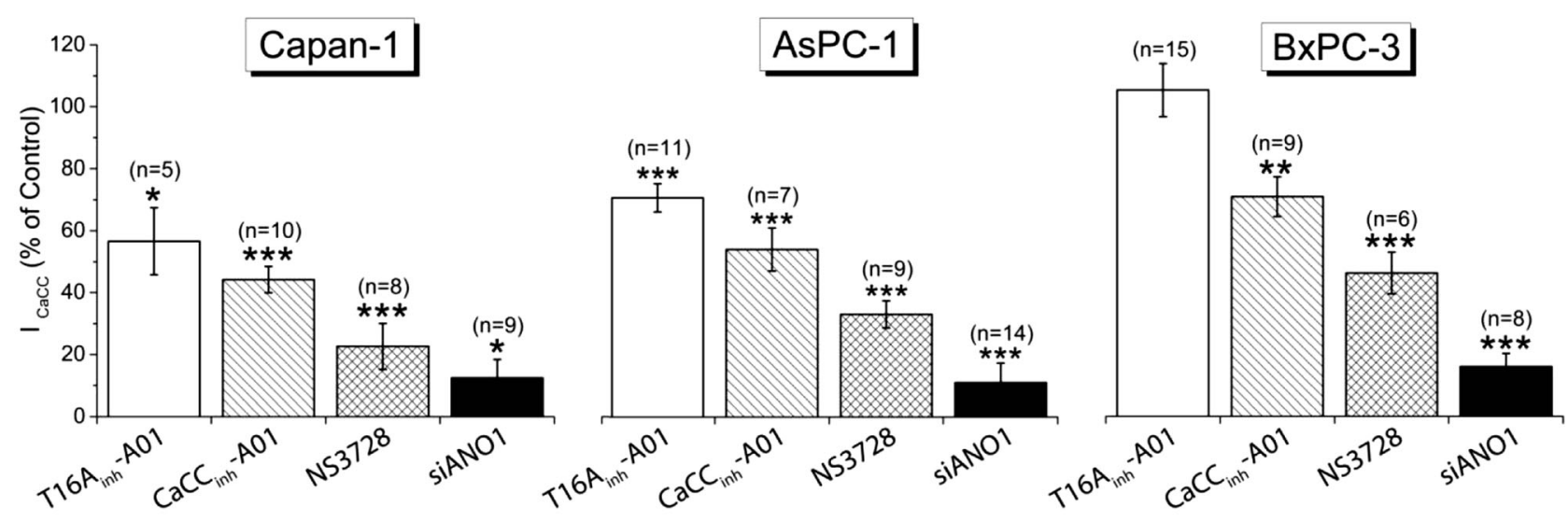

C
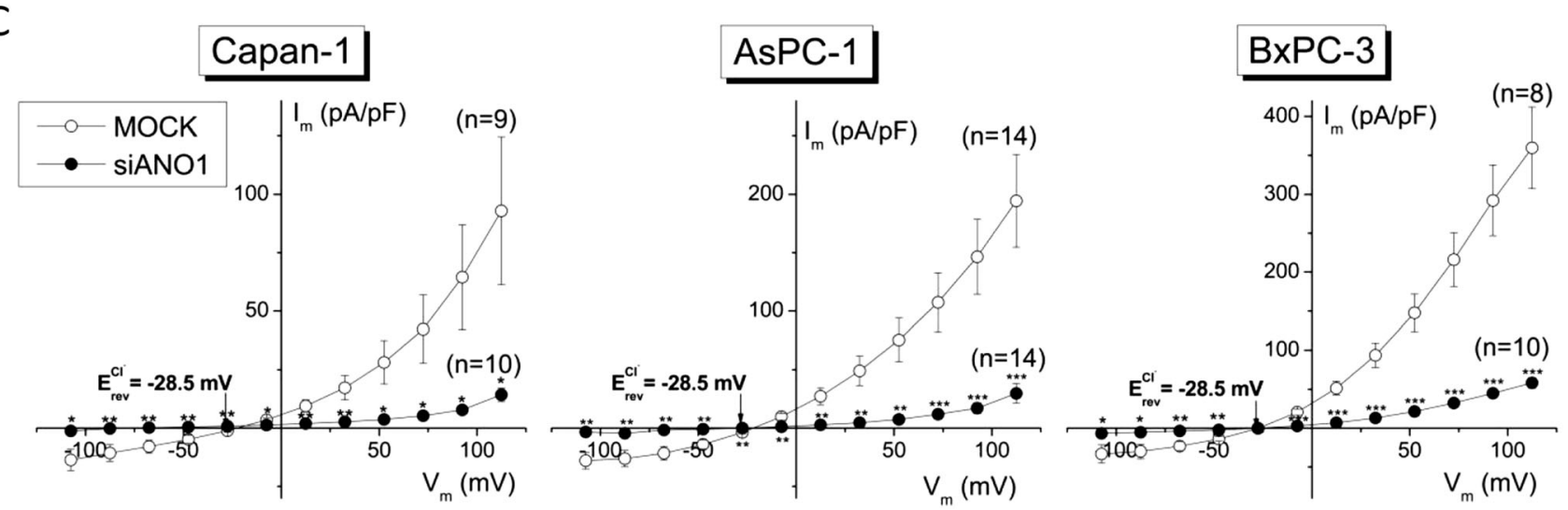

D
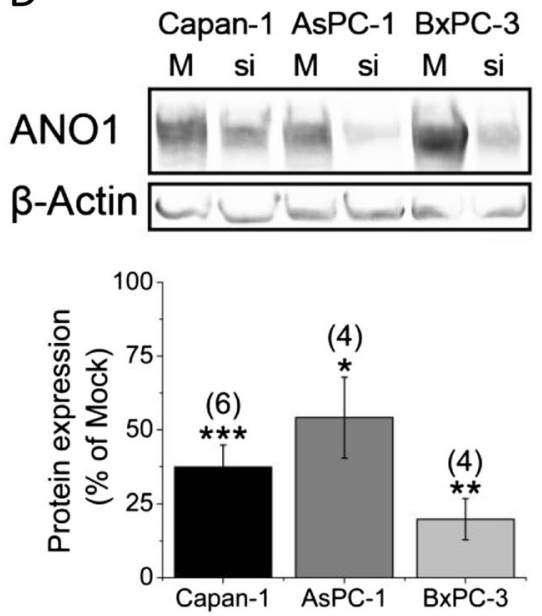
A

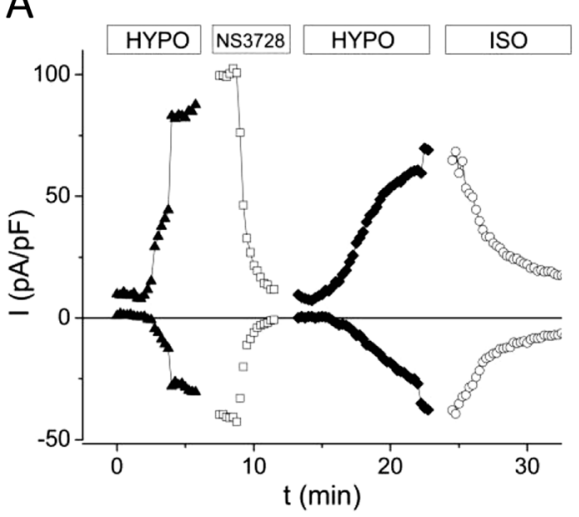

B

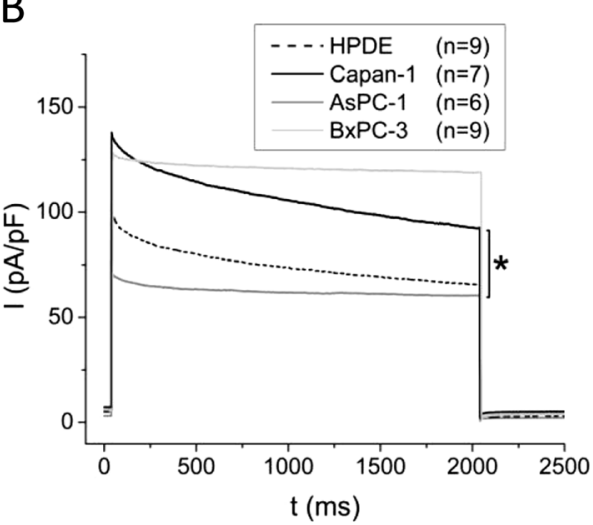

C

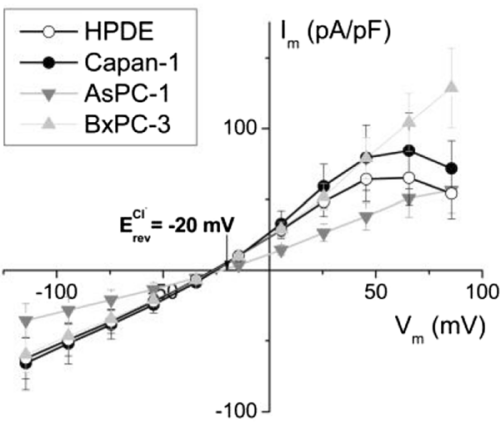

Fig. 4 All tested cell lines exhibit large swelling-activated $\mathrm{Cl}^{-}$currents. Response of whole-cell currents to hypotonic bath solution; pipette solution was $0 \mu \mathrm{M} \mathrm{Ca}^{2+}$ with $10 \mathrm{mM}$ EGTA. a Time course of currents in Capan-1 cells as described in "Materials and methods." Currents at -47

contrast, NS3728 decreased the fully activated VRAC current to $17 \pm 4 \%$ of that in the absence of the inhibitor. NS3728 was originally found to inhibit VRAC [12], but it also inhibited CaCC (Fig. 3) as also shown in another study [17]. To elucidate a possible effect of NS3728 on ANO1, we used HEK293 cells transiently transfected with mANO1-GFP as described recently [10]. Transfection with ANO1-GFP resulted in induction of a $\mathrm{Ca}^{2+}$ - and voltage-dependent, outwardly rectifying current (Fig. 6a) with a $V_{\text {rev }}$ near $E_{\mathrm{Cl}}$ (Fig. 6b). These currents were almost completely inhibited when treated with NS3728 $(10 \mu \mathrm{M}$ free concentration). The associated $\mathrm{IC}_{50}$ calculated at $V_{\mathrm{m}}=+$ $48 \mathrm{mV}$ was estimated to be $1.3 \mu \mathrm{M}$ (Fig. 6c).

\section{ANO1 plays no role in PDAC cell proliferation; VRAC does}

To assess the roles of ANO1 and VRAC in cell proliferation, we measured BrdU incorporation in mock $(5 \mathrm{nM})$ and ANO1 siRNA $(50 \mathrm{nM})$ transfected cells, as well as in the presence or and $+93 \mathrm{mV}$ were corrected for liquid junction potential, $n=24$ cells. Rate of activation varied among cells. b Currents at $+65 \mathrm{mV}$, measured using the voltage protocol described in legend of Fig. 2. c Steady-state $I-V$ relationships given as mean \pm s.e.m. $(n)=$ number of cells

absence of T16A $\mathrm{inh}_{\text {inh }}$-A01 $(20 \mu \mathrm{M}), \mathrm{CaCC}_{\mathrm{inh}}-\mathrm{A} 01(20 \mu \mathrm{M})$, NS3728 $(10 \mu \mathrm{M}$ free concentration), and the standard chemotherapeutical drug gemcitabine $(20 \mu \mathrm{M}$, not shown $)$ (Fig. 7). siRNA transfection targeting ANO1 did not cause any significant change in proliferation in any of the tested cell lines (Fig. 7a). This result indicates, quite unexpectedly, that ANO1 plays no major role in cell cycle progression. In agreement with this, none of the ANO1-overexpressing cancer cells showed any significant decrease in proliferation in response to T16 $\mathrm{A}_{\text {inh }}$-A01 (Fig. 7b). A slight, but non-significant decrease of proliferation was seen in BxPC-3 cells after $\mathrm{T} 16 \mathrm{~A}_{\mathrm{inh}}-\mathrm{A} 01$ treatment, although $\mathrm{T} 16 \mathrm{~A}_{\text {inh }}-\mathrm{A} 01$ did not affect $\mathrm{CaCC}$ currents in these cells in patch-clamp recordings. Also HPDE cells, which do not exhibit great $\mathrm{CaCC}$ (Fig. 2a), showed inhibited proliferation with $\mathrm{T}_{16 \mathrm{~A}_{\text {inh }}} \mathrm{A} 01$. The more potent inhibitor $\mathrm{CaCC}_{\text {inh- }} \mathrm{A} 01$ decreased proliferation in Capan-1 slightly and had larger effect on BxPC-3 cells. Capan-1 cells that reacted most prominently to $\mathrm{CaCC}_{\mathrm{inh}}-\mathrm{A} 01(56 \pm 6 \%$
A

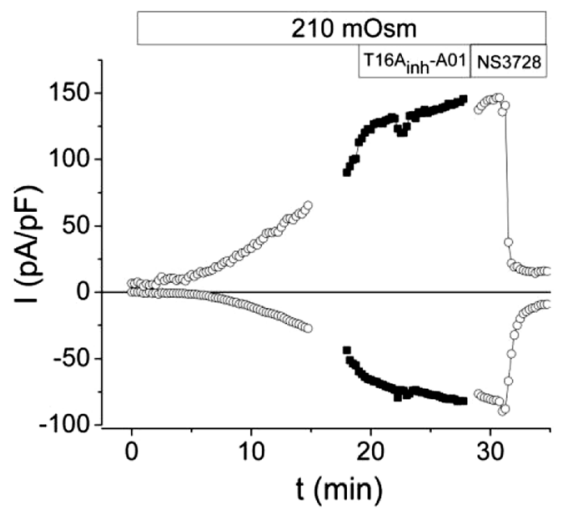

B

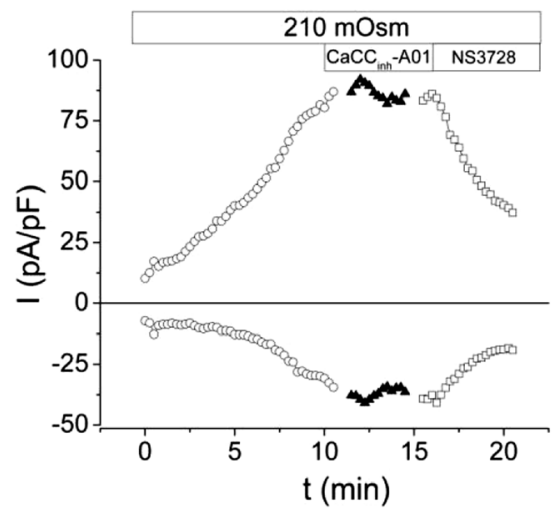

C

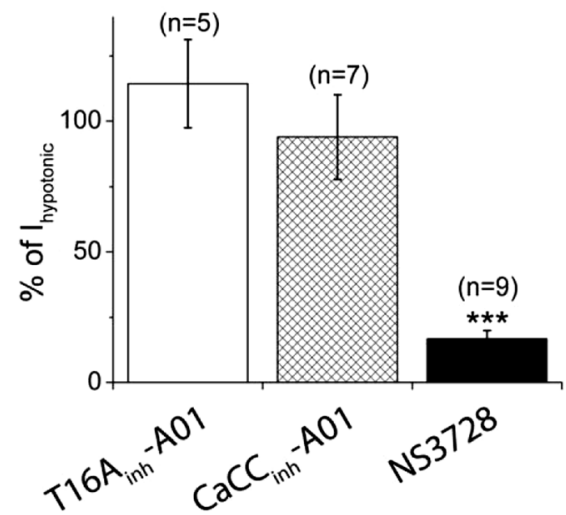

Fig. $5 \mathrm{~T} 16 \mathrm{~A}_{\text {inh }}-\mathrm{A} 01$ and $\mathrm{CaCC}_{\mathrm{inh}}-\mathrm{A} 01$ do not inhibit VRAC. a, b Representative current densities over time in HPDE and BxPC-3 cells, respectively, exposed to hypotonic bath solution and pipette solution containing $0 \mu \mathrm{M} \mathrm{Ca}^{2+}$. Inhibitors were applied for 3-10 min when the maximum volume-activated current was obtained. c Quantification of the effect shown in percent of maximum VRAC current at $+65 \mathrm{mV}$. Data shown are mean \pm s.e.m. 
Fig. 6 NS3728 inhibits ANO1 Whole-cell currents of HEK293 cells transiently transfected with mANO1-GFP with $1 \mu \mathrm{M}$ free $\mathrm{Ca}^{2+}$ in pipette solution. a Currents recorded using the step protocol with and without NS3728 $(10 \mu \mathrm{M})$ b $I-V$ relationships. $\mathrm{Cl}^{-}$equilibrium potential, $E_{\mathrm{Cl}}=-28.5 \mathrm{mV}$. c Dose-response curve of $\mathrm{NS} 3728$ at $V_{\mathrm{m}}=+48 \mathrm{mV}$. The solid line is the fit by the Hill equation ( $n=3-8$ cells, depending on concentration)
A

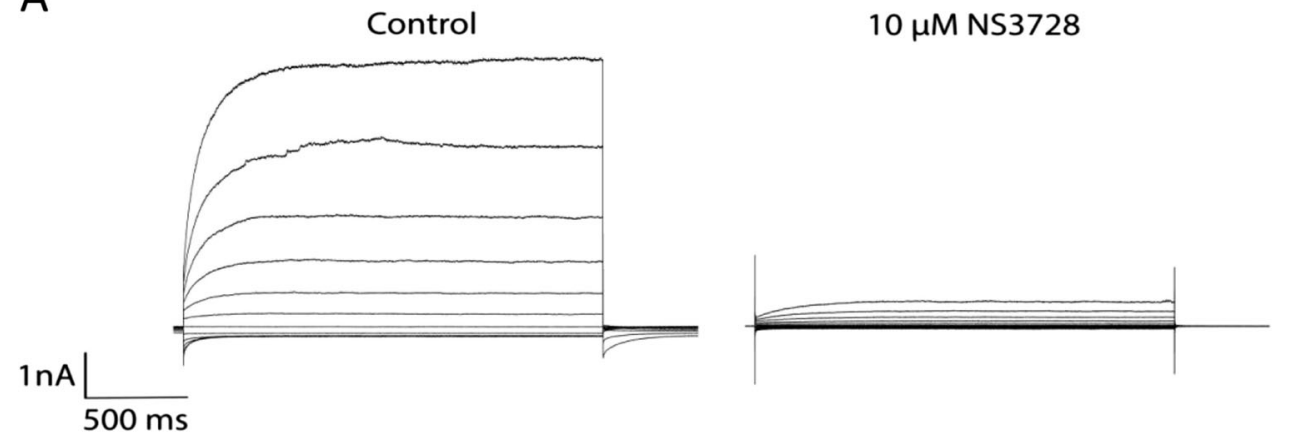

B

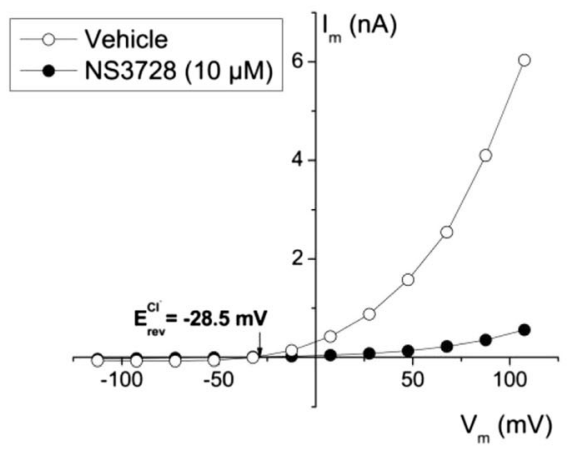

C

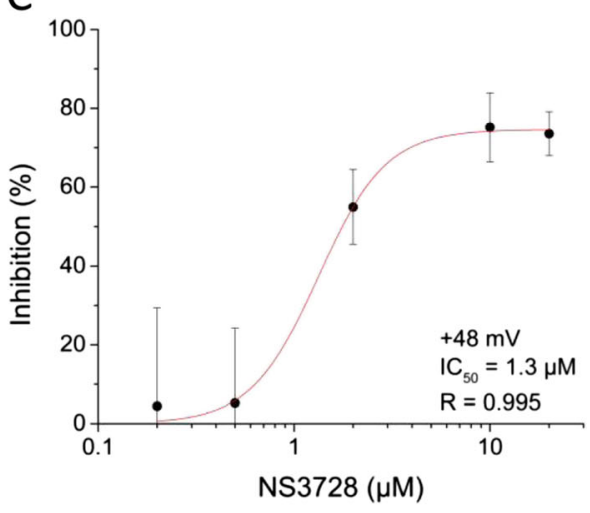

inhibition) in patch-clamp measurements showed only a slight decrease in proliferation after addition of the inhibitor.

Most importantly, Fig. 7b also shows that application of NS3728 resulted in a pronounced decrease in cellular proliferation in all cells. The most drastic effect was observed in HPDE control cells. The very low expression level of ANO1 in this cell line suggests that the inhibition of proliferation by NS3728 is not ANO1-mediated, but rather reflects inhibition of VRAC or altered $\left[\mathrm{Ca}^{2+}\right]_{\mathrm{i}}$ signaling (Fig. 8). In agreement with this, it is long known that VRAC is involved in progression throughout the cell cycle of different cancer types [17, 40]. As expected, gemcitabine treatment caused an almost complete inhibition of proliferation in all tested cells (data not shown).

All $\mathrm{Cl}^{-}$channel inhibitors alter intracellular $\mathrm{Ca}^{2+}$ signals

Activation of $\mathrm{CaCC}$ requires an increase in $\left[\mathrm{Ca}^{2+}\right]_{\mathrm{i}}$, which can be achieved by stimulation of receptors such as purinergic
Fig. 7 VRAC, but not ANO1, regulates cellular proliferation. a Summary of BrdU incorporation in HPDE, Capan-1, AsPC-1, and $\mathrm{BxPC}-3$ cells after various treatments as indicated. Cells were transfected shortly after complete attachment (approx. $3 \mathrm{~h}$ ) and BrdU incorporation was assessed $36 \mathrm{~h}$ after transfection. To investigate effect of inhibitors, cells were incubated for $24 \mathrm{~h}$ with respective inhibitor. Values shown are relative to appropriate control. Data shown represents mean \pm s.e.m. of $n=4-6$ individual experiments. ${ }^{*} p \leq 0.01$ and $* * * p \leq 0.001$ when compared with control
A

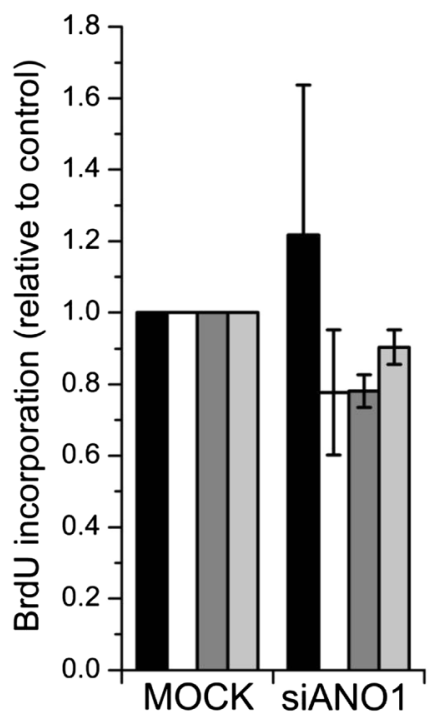

B

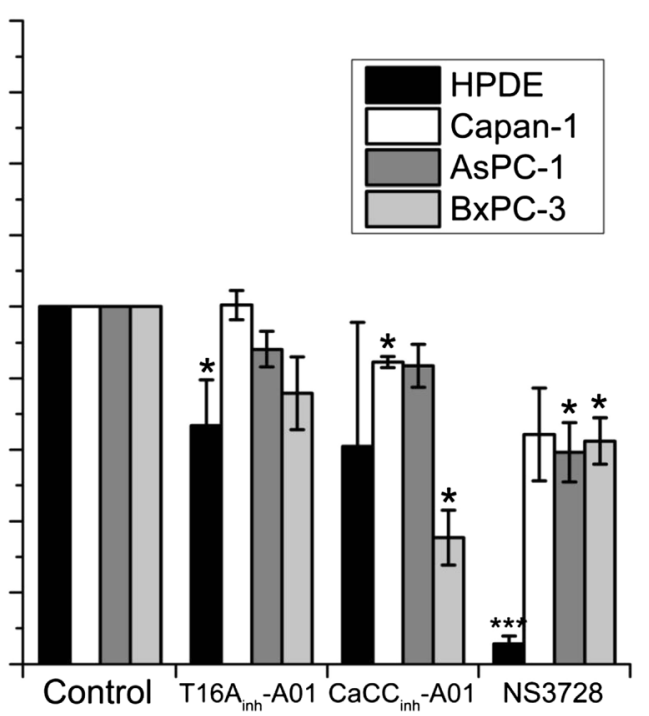



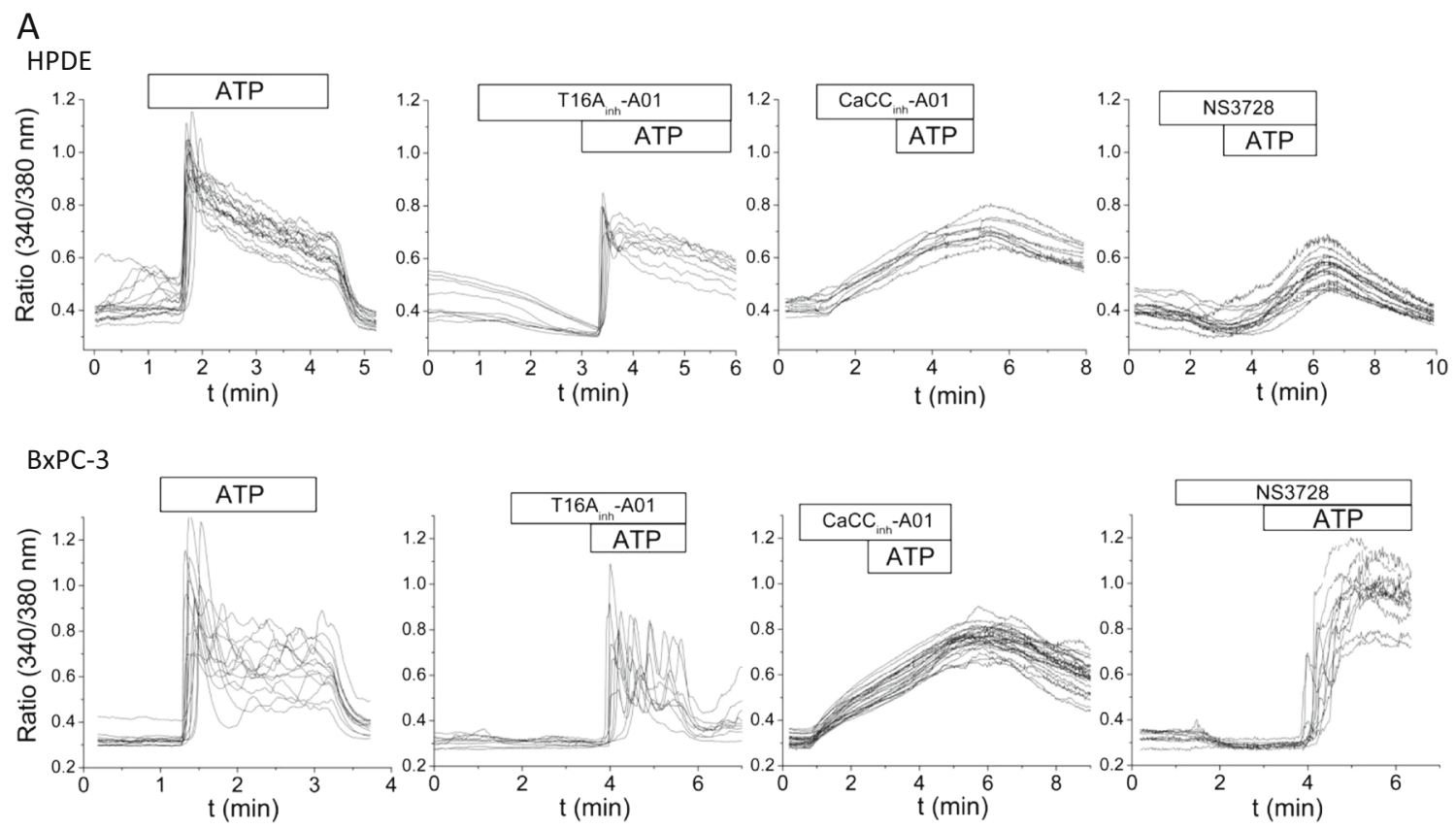

B

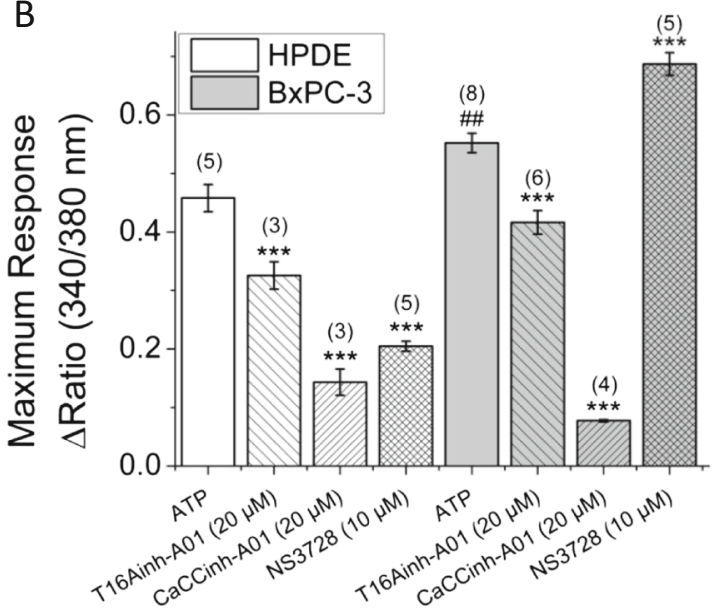

Fig. $8 \mathrm{Cl}^{-}$channel inhibitors alter ATP-induced $\mathrm{Ca}^{2+}$ signals. Intracellular $\mathrm{Ca}^{2+}$ measurements in FURA-2 loaded HPDE and BxPC-3 cells. a Representative single-cell traces of individual experiments. Different substances were applied as indicated. ATP was applied at $10 \mu \mathrm{M}$, $\mathrm{T}^{16 \mathrm{~A}_{\text {inh }}}$-A01 and $\mathrm{CaCC}_{\text {inh }}-\mathrm{A} 01$ at $20 \mu \mathrm{M}$, and NS3728 at $10 \mu \mathrm{M}$. b
Summary of maximum ATP-induced changes in $\left[\mathrm{Ca}^{2+}\right]_{i}$; for $\mathrm{CaCC}_{\mathrm{inh}}{ }^{-}$ $\mathrm{A} 01$, these values may be overestimates as the peak response was not present. $(n)=$ number of individual experiments; each containing between 5-45 single cells. ${ }^{* * *} p \leq 0.001$ when compared to no inhibitor condition; ${ }^{\#} p \leq 0.01$ when compared with HPDE no inhibitor receptors. Therefore, we studied the effect of $\mathrm{Cl}^{-}$channel inhibitors on changes in $\left[\mathrm{Ca}^{2+}\right]_{\mathrm{i}}$ induced by purinergic signaling. We chose HPDE cells with very low expression levels of ANO1 and the highly ANO1 overexpressing cell line BxPC-3 for investigation. Fura-2 loaded HPDE and BxPC-3 cells were stimulated with ATP $(10 \mu \mathrm{M})$ (Fig. 8) or exposed to the inhibitor prior to stimulation. ATP stimulation caused a 0.46 \pm 0.03 peak increase in the Fura- 2 ratio in HPDE and $0.55 \pm$ 0.02 in BxPC-3 cells. Cells first exposed to $\mathrm{T}_{16 \mathrm{~A}_{\text {inh }}}$ A01 showed a significantly attenuated peak response to ATP resulting in a $0.32 \pm 0.03$ (HPDE) and $0.42 \pm 0.03$ (BxPC-3) change in Fura-2 ratio (Fig. 8). However, no effect of the inhibitor on basal $\mathrm{Ca}^{2+}$ level was observed. Exposure to $\mathrm{CaCC}_{\mathrm{inh}}-\mathrm{A} 01(20 \mu \mathrm{M})$ caused a reversible increase in $\left[\mathrm{Ca}^{2+}\right]_{\mathrm{i}}$ in both cell lines tested. Subsequent application of ATP elicited no additional effect on top of inhibitor-induced $\left[\mathrm{Ca}^{2+}\right]_{i}$ increase. No significant change in basal $\left[\mathrm{Ca}^{2+}\right]_{\mathrm{i}}$ was observed in HPDE and BxPC-3 cells when exposed to NS3728 $(10 \mu \mathrm{M})$. Pretreatment with NS3728 caused a significantly attenuated response in HPDE cells $(0.21 \pm 0.01 \Delta$ ratio $340 /$ $380 \mathrm{~nm}$ ). In contrast, in BxPC-3 cells, NS3728 pretreatment elicited a prolonged increase in $\left[\mathrm{Ca}^{2+}\right]_{\mathrm{i}}$ upon ATP stimulation. The responses are summarized in Fig. 8b. 
A

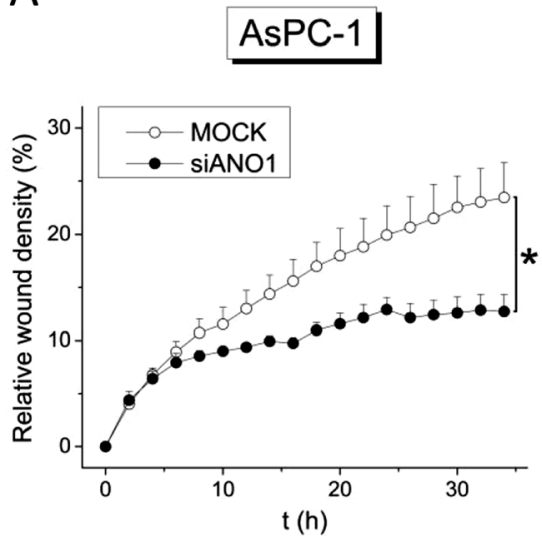

Fig. 9 ANO1 supports migration of PDAC cells. Wound healing assay is shown as relative wound density (density of wounded area relative to confluency of cell region) over time. Aphidicolin $(5 \mu \mathrm{M})$ was added to stop proliferation. a AsPC-1 cells and $\mathbf{b}$ BxPC-3 cells after transfection

ANO1 is crucial for cell migration

Earlier studies already revealed ANO1 as a crucial player in cell migration $[15,35]$. We therefore assessed a possible contribution of ANO1 in PDAC cell migration using wound healing assay. Capan-1 cells did not show any wound closure in this time frame and were therefore not investigated. The experiments were conducted in the presence of $5 \mu \mathrm{M}$ aphidicolin to rule out a possible effect on cell proliferation. Figure 9a shows relative wound density (see Materials and Methods) over time, monitored in AsPC-1 cells transfected with either scrambled siRNA (5 $\mathrm{nM})(\mathrm{MOCK})$ or siRNA targeting ANO1 (50 nM). ANO1 knockdown cells showed a significantly decreased migration (Fig. 9a). However, the relative wound density curve over time saturated after $36 \mathrm{~h}$ and only partial wound closure $(24 \pm 4 \%)$ was reached in the control situation. AsPC-1 cells were therefore not well suited for studies of lateral motility. BxPC-3 cells showed a much more rapid wound closure with complete closure after $60 \mathrm{~h}$ in most of the control experiments. Migration was significantly decreased to $30 \pm 8 \%$ after $60 \mathrm{~h}$ after transfection with siANO1 (Fig. 9b). In another series of experiments, we exposed the cells to $\mathrm{T}_{16 \mathrm{~A}_{\text {inh }}-\mathrm{A} 01}(20 \mu \mathrm{M}), \mathrm{CaCC}_{\text {inh }}-\mathrm{A} 01 \quad(20 \mu \mathrm{M})$, and NS3728 (10 $\mu \mathrm{M}$ free concentration) (Fig. 9c). Application of $\mathrm{T}_{16 \mathrm{~A}_{\text {inh }}} \mathrm{A} 01$ had no detectable effect on migratory behavior. $\mathrm{CaCC}_{\mathrm{inh}}-\mathrm{A} 01$ seemed to slow down wound closure; however, this did not reach significance. When exposed to NS3728, an initial acceleration was observed that began to saturate after $30 \mathrm{~h}$ and resulted in $54 \pm 8 \%$ relative wound density after $60 \mathrm{~h}$. All inhibitors were applied at several orders of magnitude above the $\mathrm{IC}_{50}$ value for $\mathrm{ANO} 1$, yet none caused effects on wound closure comparable to those observed in the knockdown cells. These results are in good
C
BxPC-3

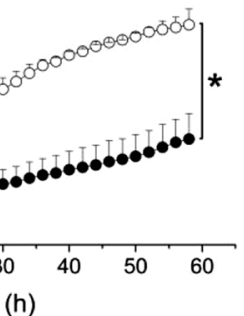

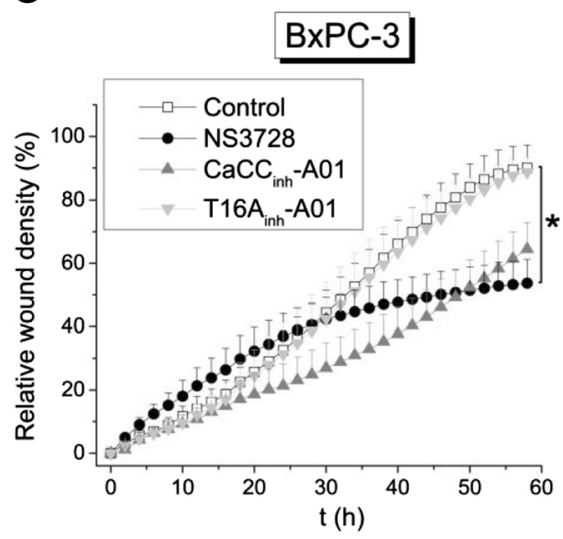

with either scrambled siRNA $(5 \mathrm{nM})$ or siRNA targeting ANO1 $(50 \mathrm{nM})$. c BxPC-3 cells in presence of different inhibitors. Data shown represents mean \pm s.e.m. of $n=4$ experiments; each run was carried out in triplicates

agreement with whole-cell patch-clamp recordings of CaCC currents, in which ANO1 knockdown also showed the strongest inhibitory effect (Fig. 3).

\section{Discussion}

In the present study, we provided compelling evidence that ANO1 is functionally overexpressed in human pancreatic cancer cell lines and that it carries the major component of $\mathrm{CaCC}$ currents in these cells. Below, we discuss the possible roles of ANO1 in PDAC cell behavior, as well as some unexpected effects of putative ANO1 inhibitors.

$\mathrm{All} \mathrm{Cl}^{-}$channel inhibitors inhibit $\mathrm{CaCC}$ but also have other side effects

siRNA knockdown of ANO1 almost completely abolished the CaCC-mediated current in all cells tested. Surprisingly, to date, the most specific inhibitor of ANO1, T16 $\mathrm{A}_{\mathrm{inh}} \mathrm{A}-\mathrm{A} 01$ [24], did not inhibit the CaCC current in BxPC-3 cells, even when applied several orders of magnitude above the $\mathrm{IC}_{50}$ value for ANO1 $(20 \mu \mathrm{M})$ [24]. Inhibition was observed in other PDAC cells, but efficacy was still only moderate (Capan-1 and AsPC-1 cells) (Fig. 3). A recent study by Scudieri et al. of ANO1 in bronchial epithelial cells reports similar observations [39]. They found that siRNA targeting ANO1 diminished $\mathrm{Ca}^{2+}$-activated $\mathrm{Cl}^{-}$secretion almost entirely, yet $\mathrm{T} 16 \mathrm{~A}_{\mathrm{inh}}$-A01 $(10 \mu \mathrm{M})$ showed relatively weak inhibition. Moreover, these researchers found that cells prior exposed to $\mathrm{T} 16 \mathrm{~A}_{\text {inh- }} \mathrm{A} 01(10 \mu \mathrm{M})$ had significantly attenuated UTP-induced $\mathrm{Cl}^{-}$secretion in short-circuit currents recordings. This is in line with our measurements of attenuated ATPinduced increase in $\left[\mathrm{Ca}^{2+}\right]_{\mathrm{i}}$ in the presence of this inhibitor 
(Fig. 8). We also observed off-target effects of $\mathrm{T} 16 \mathrm{~A}_{\text {inh }}-\mathrm{A} 01$ when applied in proliferation experiments. The inhibitor resulted in a significant inhibition of proliferation in HPDE cells, which almost completely lack ANO1 (Figs. 1, 2, and 7) and yet have attenuated response to ATP-induced $\left[\mathrm{Ca}^{2+}\right]_{i}$ signals. Taken together, these results suggest that $\mathrm{T} 16 \mathrm{~A}_{\text {inh }^{-}}$ A01 is not suited as a specific inhibitor of ANO1 and that its mechanism of action might either be more indirect or may depend on the type of cell, ANO1 isoforms and/or experimental conditions.

$\mathrm{CaCC}_{\text {inh- }}$-A01 inhibited $\mathrm{CaCC}$ current stronger in all cell lines tested (Fig. 3). No effect of $\mathrm{CaCC}_{\text {inh }}$-A01 on VRAC was observed (Fig. 5b). However, we revealed large unspecific effects of the inhibitor on $\left[\mathrm{Ca}^{2+}\right]_{\mathrm{i}}$ which slowly increased with the inhibitor, ATP stimulation had no further effects, and the effects were fully reversible (Fig. 8). Similar unspecific effects of the inhibitor were also observed by others [18]. $\mathrm{CaCC}_{\mathrm{inh}}{ }^{-}$ A01 was further reported to inhibit other CaCCs [18].

The third inhibitor used in this investigation, NS3728, also has limited specificity. It is an inhibitor of VRAC and ANO1 (Figs. 4 and 6), but may also inhibit other molecular entities involved in $\mathrm{CaCC}$ [17]. We further found that NS3728 altered ATP-induced $\left[\mathrm{Ca}^{2+}\right]_{\mathrm{i}}$ signals in a cell line-dependent fashion (Fig. 8), such that PDAC cells were even more responsive to ATP. Our study thus illustrates that presently available inhibitors are problematic and more selective inhibitors are still required.

ANO1 has no role in cell proliferation but supports migration

The physiological role of $\mathrm{CaCC}$ (e.g., ANO1) in pancreatic ducts is in mediating secretion $[25,45]$. One of the interesting questions is how overexpression of this channel could regulate other cellular functions in PDAC. We found no correlation between ANO1 protein level and cell proliferation (Figs. 1 and 7) or effector caspase activation after gemcitabine treatment (online resources Fig. S1) in any of the tested cells. Our findings are in agreement with recent reports on head and neck squamous cell carcinoma cells, where no correlation between ANO1 expression and channels function (siRNA knockdown or $\left.\mathrm{CaCC}_{\mathrm{inh}}-\mathrm{A} 01\right)$ and cell proliferation was found [1, 35]. However, these results stand in contrast to reports in which ANO1 was shown to play a pro-proliferative role in cancer cells. These studies use different approaches covering xenograft models [7], RNAi knockdown [22], as well as smallmolecule inhibitors [23]. The latter study was entirely based on $\mathrm{T}_{16 \mathrm{~A}_{\text {inh }}} \mathrm{A} 01$ and uses the pancreatic cancer cell line CFPAC-1, which has also a defect in another $\mathrm{Cl}^{-}$channels (i.e., CFTR). Unspecific effects of the inhibitor as shown in the present investigation may explain these results. However, the function of ANO1 in cell proliferation may depend on cell environment, cell type, or other factors. The most significant decrease in proliferation of PDAC cell lines was observed with NS3728 exposure, an effect which can probably be assigned to inhibition of VRAC and cell volume regulation. In addition, altered $\left[\mathrm{Ca}^{2+}\right]_{\mathrm{i}}$ signaling, as shown in Fig. 8, may also contribute to NS3728-mediated inhibition of cell proliferation. Taken together, no correlation between ANO1 expression and PDAC cell proliferation was observed in the present study. However, our results once again highlight the importance of VRAC in proliferation previously shown in several cell types [13].

Most importantly, we found that siRNA knockdown of ANO1 resulted in a significantly decreased migratory rate in both AsPC-1 and BxPC-3 cells (Fig. 9). This pro-migratory role of ANO1 was further confirmed by pharmacological inhibition of the channel. Thus, $\mathrm{CaCC}_{\text {inh- }}-\mathrm{A} 01$ and NS3728 caused a decrease in migration in BxPC- 3 cells, whereas $\mathrm{T}_{16 \mathrm{~A}} \mathrm{inh}_{\mathrm{A}} \mathrm{A} 01$ was found to be ineffective. These results correlate directly with the inhibitory potential of these inhibitors on $\mathrm{CaCC}$ current (Fig. 3b), suggesting that ANO1 functions as an ion channel which has a crucial role in supporting migration. These results fit with the commonly accepted model for cell migration, where cell shape changes caused by local volume changes are driven by fluxes of $\mathrm{K}^{+}$and $\mathrm{Cl}^{-}$ions and accompanied by $\mathrm{H}_{2} \mathrm{O}$ [38]. We and others provided compelling evidence that ANO1 is involved in the migratory machinery in other cell types $[15,35]$. On the other hand, Capan-1 cells, which showed the highest functional ANO1 expression in the present study, migrate very slowly, whereas HPDE cells which are almost devoid of ANO1 showed fast wound closure in a scratch assay (data not shown). This indicates that whereas $\mathrm{Cl}^{-}$currents are likely a prerequisite to cell migration, the current need not be carried by ANO1. In HPDE cells, VRAC may be a possible candidate.

Our study points out that to further target the functions of ANO1 and VRAC in cancers overexpressing these currents, development of more selective small-molecule inhibitors would be useful. In conclusion, our study shows that ANO1 is functionally overexpressed in PDAC cells and its role is related to cell migration but not to proliferation. ANO1 may therefore pose a good target for control of metastatic potential of PDAC.

Acknowledgments This work was supported by the Marie Curie Initial Training Network IonTraC (Grant Agreement No. 289648) and by The Danish Council for Independent Research/Natural Sciences (grant 10 085217). The HPDE cell line was a kind gift of Dr. M-S. Tsao from University Health Network in Toronto. NS3728 was a generous gift from Palle Christophersen (NeuroSearch A/S, Denmark). The mANO1-GFP vector was generated by Kristian Poulsen and Niels Bjerre Holm. The authors thank Thomas Kjœr Klausen for fruitful discussions and technical support, Pernille Roshof and Birthe Juul Hansen for technical assistance.

Conflict of interest None of the authors have any conflict of interests.

Ethical standards All experiments were carried out in compliance to the current laws of the country. 
Open Access This article is distributed under the terms of the Creative Commons Attribution License which permits any use, distribution, and reproduction in any medium, provided the original author(s) and the source are credited.

\section{References}

1. Ayoub C, Wasylyk C, Li Y, Thomas E, Marisa L, Robé A, Roux M, Abecassis J, de Reyniès A, Wasylyk B (2010) ANO1 amplification and expression in HNSCC with a high propensity for future distant metastasis and its functions in HNSCC cell lines. Br J Cancer 103(715-26):2010

2. Bergmann F, Andrulis M, Hartwig W, Penzel R, Gaida MM, Herpel E, Schirmacher P, Mechtersheimer G (2011) Discovered on gastrointestinal stromal tumor 1 (DOG1) is expressed in pancreatic centroacinar cells and in solid-pseudopapillary neoplasms - novel evidence for a histogenetic relationship. Hum Pathol 42:817-823

3. Britschgi A, Bill A, Brinkhaus H, Rothwell C, Clay I, Duss S, Rebhan M, Raman P, Guy CT, Wetzel K, George E, Popa MO, Lilley S, Choudhury H, Gosling M, Wang L, Fitzgerald S, Borawski J, Baffoe J, Labow M, Gaither LA, Bentires-Alj M (2013) Calcium-activated chloride channel ANO1 promotes breast cancer progression by activating EGFR and CAMK signaling. PNAS 110:E1026-E1034

4. Caputo A, Caci E, Ferrera L, Pedemonte N, Barsanti C, Sondo E, Pfeffer U, Ravazzolo R, Zegarra-Moran O, Galietta LJV (2008) TMEM16A, a membrane protein associated with calciumdependent chloride channel activity. Science 322:590-594

5. Davis AJ, Shi J, Pritchard HA, Chadha PS, Leblanc N, Vasilikostas G, Yao Z, Verkman A, Albert AP, Greenwood IA (2013) Potent vasorelaxant activity of the TMEM16A inhibitor T16Ainh-A01. Br J Pharmacol 168:773-784

6. Deer EL, González-Hernández J, Coursen JD, Shea JE, Ngatia J, Scaife CL, Firpo MA, Mulvihill SJ (2010) Phenotype and genotype of pancreatic cancer cell lines. Pancreas 39:425-435

7. Duvvuri U, Shiwarski DJ, Xiao D, Bertrand C, Huang X, Edinger RS, Rock JR, Harfe BD, Henson BJ, Kunzelmann K, Schreiber R, Seethala RS, Egloff AM, Chen X, Lui VW, Grandis JR, Gollin SM (2012) TMEM16A induces MAPK and contributes directly to tumorigenesis and cancer progression. Cancer Res 72:3270-3281

8. Furukawa T, Duguid W, Rosenberg L, Viallet J, Galloway D, Tsao M (1996) Short communication long-term culture and immortalization of epithelial cells from normal adult human. Am J Pathol 148:1763-1770

9. Galietta LJ (2009) The TMEM16 protein family: a new class of chloride channels? Biophys J 97:3047-3053

10. Grubb S, Poulsen K, Juul CA, Kyed T, Klausen TK, Larsen EH, Hoffmann EK (2013) TMEM16F (Anoctamin 6), an anion channel of delayed $\mathrm{Ca}^{2+}$ activation. J Gen Physiol 141:585-600

11. Hanahan D, Weinberg R (2011) Hallmarks of cancer: the next generation. Cell 144:646-674

12. Hélix N, Strøbaek D, Dahl BH, Christophersen P (2003) Inhibition of the endogenous volume-regulated anion channel (VRAC) in HEK293 cells by acidic di-aryl-ureas. J Membr Biol 196:83-94

13. Hoffmann EK, Holm NB, Lambert IH (2014) Functions of volumesensitive and calcium-activated chloride channels. IUBMB Life 66: 257-267

14. Hoffmann EK, Lambert I, Pedersen SF (2009) Physiology of cell volume regulation in vertebrates. Physiol Rev 89:193-277

15. Jacobsen KS, Zeeberg K, Sauter DRP, Poulsen K, Hoffmann EK, Schwab A (2013) The role of TMEM16A (ANO1) and TMEM16F (ANO6) in cell migration. Pflugers Arch 465:1753-1762

16. Jones S, Zhang X, Parsons DW, Lin JC-H, Leary RJ, Angenendt P, Mankoo P, Carter H, Kamiyama H, Jimeno A, Hong S-M, Fu B, Lin M-T, Calhoun ES, Kamiyama M, Walter K, Nikolskaya T, Nikolsky Y, Hartigan J, Smith DR, Hidalgo M, Leach SD, Klein AP, Jaffee
EM, Goggins M, Maitra A, Iacobuzio-Donahue C, Eshleman JR, Kern SE, Hruban RH, Karchin R, Papadopoulos N, Parmigiani G, Vogelstein B, Velculescu VE, Kinzler KW (2008) Core signaling pathways in human pancreatic cancers revealed by global genomic analyses. Science 321:1801-1806

17. Klausen TK, Bergdahl A, Hougaard C, Christophersen P, Pedersen SF, Hoffmann EK (2007) Cell cycle-dependent activity of the volume- and $\mathrm{Ca}^{2+}$-activated anion currents in Ehrlich Lettre ascites. Cells 842:831-842

18. Kunzelmann K, Schreiber R, Kmit A, Jantarajit W, Martins JR, Faria D, Kongsuphol P, Ousingsawat J, Tian Y (2012) Expression and function of epithelial anoctamins. Exp Physiol 97:184-192

19. Lang F, Hoffmann E (2012) Role of ion transport in control of apoptotic. Compr Physiol 2:1-25

20. Lee G-W, Park HS, Kim E-J, Cho Y-W, Kim G-T, Mun Y-J, Choi E-J, Lee J-S, Han J, Kang D (2012) Reduction of breast cancer cell migration via up-regulation of TASK-3 two-pore domain $\mathrm{K}^{+}$channel. Acta Physiol (Oxf) 204:513-524

21. Lehen'kyi V, Shapovalov G, Skryma R, Prevarskaya N (2011) Ion channels and transporters in cancer. 5. Ion channels in control of cancer and cell apoptosis. Am J Physiol Cell Physiol 301:C1281-C1289

22. Liu W, Lu M, Liu B, Huang Y, Wang K (2012) Inhibition of $\mathrm{Ca}^{2+}$ activated $\mathrm{Cl}^{-}$channel ANO1/TMEM16A expression suppresses tumor growth and invasiveness in human prostate carcinoma. Cancer Lett 326:41-51

23. Mazzone A, Eisenman ST, Strege PR, Yao Z, Ordog T, Gibbons SJ, Farrugia $G$ (2012) Inhibition of cell proliferation by a selective inhibitor of the $\mathrm{Ca}^{2+}$ - activated $\mathrm{Cl}^{-}$channel, Ano1. Biochem Biophys Res Commun 427:248-253

24. Namkung W, Phuan P-W, Verkman A (2011) TMEM16A inhibitors reveal TMEM16A as a minor component of calcium-activated chloride channel conductance in airway and intestinal epithelial cells. J Biol Chem 286:2365-2374

25. Novak I, Haanes K, Wang J (2013) Acid-base transport in pancreasnew challenges. Front Physiol 4:1-7

26. Ormandy CJ, Musgrove EA, Hui R, Daly RJ, Sutherland RL (2003) Cyclin D1, EMS1 and 11q13 amplification in breast cancer. Breast Cancer Res Treat 78:323-335

27. Ouyang H, Mou L, Luk C, Liu N, Karaskova J, Squire J, Tsao MS (2000) Immortal human pancreatic duct epithelial cell lines with near normal genotype and phenotype. Am J Pathol 157:1623-1631

28. Pardo LA, Stühmer W (2014) The roles of $\mathrm{K}^{+}$channels in cancer. Nat Rev Cancer 14:39-48

29. Pedersen SF, Hoffmann EK, Novak I (2013) Cell volume regulation in epithelial physiology and cancer. Front Physiol 4:233

30. Pedersen S, Prenen J, Droogmans G, Hoffmann E, Nilius B (1998) Separate swelling- and $\mathrm{Ca}^{2+}$-activated anion currents in Ehrlich ascites tumor cells. J Membr Biol 110:97-110

31. Pedersen SF, Stock C (2013) Ion channels and transporters in cancer: pathophysiology, regulation, and clinical potential. Cancer Res 73: 1658-1661

32. Ponce A, Jimenez-Peña L, Tejeda-Guzman C (2012) The role of swelling-activated chloride currents (I(CL, swell)) in the regulatory volume decrease response of freshly dissociated rat articular chondrocytes. Cell Physiol Biochem 30:1254-1270

33. Poulsen K, Andersen EC, Hansen CF, Klausen TK, Hougaard C, Lambert IH, Hoffmann EK (2010) Deregulation of apoptotic volume decrease and ionic movements in multidrug-resistant tumor cells: role of chloride channels. Am J Physiol Cell Physiol 298:C14-C25

34. Qiu Z, Dubin AE, Mathur J, Tu B, Reddy K, Miraglia LJ, Reinhardt J, Orth AP, Patapoutian A (2014) SWELL1, a plasma membrane protein, is an essential component of volume-regulated anion channel. Cell 157:447-458

35. Ruiz C, Martins JR, Rudin F, Schneider S, Dietsche T, Fischer CA, Tornillo L, Terracciano LM, Schreiber R, Bubendorf L, Kunzelmann K (2012) Enhanced expression of ANO1 in head and neck squamous 
cell carcinoma causes cell migration and correlates with poor prognosis. PLoS One 7:1-12

36. Schmittgen TD, Livak KJ (2008) Analyzing real-time PCR data by the comparative CT method. Nat Protoc 3:1101-1108

37. Schroeder BC, Cheng T, Jan YN, Jan LY (2008) Expression cloning of TMEM16A as a calcium-activated chloride channel subunit. Cell 134:1019-1029

38. Schwab A, Fabian A, Hanley PJ, Stock C (2012) Role of ion channels and transporters in cell migration. Physiol Rev 92:1865-1913

39. Scudieri P, Caci E, Bruno S, Ferrera L, Schiavon M, Sondo E, Tomati V, Gianotti A, Zegarra-Moran O, Pedemonte N, Rea F, Ravazzolo R, Galietta LJV (2012) Association of TMEM16A chloride channel overexpression with airway goblet cell metaplasia. J Physiol 590:6141-6155

40. Shen MR, Droogmans G, Eggermont J, Voets T, Ellory JC, Nilius B (2000) Differential expression of volume-regulated anion channels during cell cycle progression of human cervical cancer cells. J Physiol 529(Pt 2):385-394

41. Sheridan J, Worthingtone E, Kuai Y, Sherif E, Hartzell HC, Tarran R (2011) Characterization of the oligomeric structure of the $\mathrm{Ca}^{2+}$-activated $\mathrm{Cl}^{-}$channel Ano1/TMEM16A. J Biol Chem 286(1381-1388):2011

42. Sipos B, Möser S, Kalthoff H, Török V, Löhr M, Klöppel G (2003) A comprehensive characterization of pancreatic ductal carcinoma cell lines: towards the establishment of an in vitro research platform. Virchows Arch 442:444-452
43. Voloshyna I, Besana A, Castillo M, Matos T, Weinstein IB, Mansukhani M, Robinson RB, Cordon-Cardo C, Feinmark SJ (2008) TREK-1 is a novel molecular target in prostate cancer. Cancer Res 68:1197-1203

44. Voss FK, Ullrich F, Münch J, Lazarow K, Lutter D, Mah N, Andrade-Navarro MA, von Kries JP, Stauber T, Jentsch TJ (2014) Identification of LRRC8 heteromers as an essential component of the volume-regulated anion channel VRAC. Science 344:634-638

45. Wang J, Haanes K, Novak I (2013) Purinergic regulation of CFTR and $\mathrm{Ca}^{2+}$-activated $\mathrm{Cl}^{-}$channels and $\mathrm{K}^{+}$channels in human pancreatic duct epithelium. Am J Physiol Cell Physiol 304:673-684

46. Wanitchakool P, Wolf L, Koehl GE, Sirianant L, Schreiber R, Kulkarni S, Duvvuri U, Kunzelmann K (2014) Role of anoctamins in cancer and apoptosis. Phil Trans R Soc B 369:1-8

47. Xiao Q, Yu K, Perez-Cornejo P, Cui Y, Arreola J, Hartzell HC (2011) Voltage- and calcium-dependent gating of TMEM16A/Ano1 chloride channels are physically coupled by the first intracellular loop. Proc Natl Acad Sci U S A 108:8891-8896

48. Yang YD, Cho H, Koo JY, Tak MH, Cho Y, Shim W-S, Park SP, Lee J, Lee B, Kim B-M, Raouf R, Shin YK, Oh U (2008) TMEM16A confers receptor-activated calcium-dependent chloride conductance. Nature 455:1210-1215 